\title{
Cellulolytic enzyme-producing thermophilic Actinobacteria isolated from the soil of Cisolok Geysers, West Java, Indonesia
}

\author{
PUTRI PRATIWI SETYANINGSIH ${ }^{1, *}$, FITRIA NINGSIH ${ }^{1,2, *}$, MAZYTHA KINANTI RACHMANIA ${ }^{1}$, \\ WINDA AYU SYAFITRI ${ }^{1}$, DHIAN CHITRA AYU FITRIA SARI ${ }^{1,2}$, SHUHEI YABE ${ }^{3,4}$, AKIRA YOKOTA ${ }^{3}$, \\ ARIYANTI OETARI ${ }^{1,2}$, WELLYZAR SJAMSURIDZAL ${ }^{1,2, \varphi}$ \\ ${ }^{1}$ Department of Biology, Faculty of Mathematics and Natural Sciences, Universitas Indonesia. Jl. Prof. DR. Sudjono D. Pusponegoro, Kampus UI Depok, \\ Depok 16424, West Java, Indonesia \\ ${ }^{2}$ Center of Excellence for Indigenous Biological Resources-Genome Studies, Faculty of Mathematics and Natural Sciences, Universitas Indonesia. \\ Jl. Prof. DR. Sudjono D. Pusponegoro, Kampus UI Depok, Depok 16424, West Java, Indonesia. Tel.: +62-21-7270163, Fax.: +62-21-78849010, \\ remail: sjwelly@ hotmail.com; sjwelly@sci.ui.ac.id \\ ${ }^{3}$ Department of Microbial Resources, Graduate School of Agricultural Sciences, Tohoku University, 468-1 Aoba, Aramaki, Aoba-ku, Sendai, Miyagi \\ 980-0845, Japan \\ ${ }^{4}$ Hazaka Plant Research Center, Kennan Eisei Kogyo Co., Ltd., 44 Aza-Inariyama, Oaza-Ashitate, Murata-cho, Shibata-gun, Miyagi 989-1311, Japan \\ *These authors contributed equally to the work
}

Manuscript received: 8 August 2019. Revision accepted: 8 October 2019

\begin{abstract}
Setyaningsih PP, Ningsih F, Rachmania MK, Syafitri WA, Sari DCAF, Yabe S, Yokota A, Oetari A, Sjamsuridzal W. 2019. Cellulolytic enzyme-producing thermophilic Actinobacteria isolated from the soil of Cisolok Geysers, West Java, Indonesia. Biodiversitas 20: 3134-3141. This study investigated 17 thermophilic Actinobacteria isolated from the soil of geysers in the Cisolok geothermal area, West Java, as potential producers of cellulase. Screening for cellulase was performed on minimal (Mm) agar medium with and without the addition of $1 \%(\mathrm{w} / \mathrm{v})$ carboxymethylcellulose (CMC) and microcrystalline cellulose (MCC), then incubated at 45, 50,55 and $60^{\circ} \mathrm{C}$ for up to 7 days. Formation of clear zones around colonies indicated cellulose hydrolysis. The results showed that 15 , 14,4 , and 3 isolates showed cellulolytic activity on CMC agar medium at $45,50,55$, and $60^{\circ} \mathrm{C}$, respectively, after 7 days of incubation. Three potential isolates showed cellulolytic activity on MCC agar medium after being incubated for 7 days at $45^{\circ} \mathrm{C}$. Molecular identification based on the $16 \mathrm{~S}$ rRNA gene was performed for three isolates with positive cellulolytic activity at $60^{\circ} \mathrm{C}$. The results showed that the three isolates are closely related to Actinomadura keratinilytica WCC-2265 ${ }^{\mathrm{T}}$ with $99.93-100 \%$ sequence similarities. A phylogenetic tree based on 16S rRNA gene sequences confirmed that the three isolates were clustered together with Actinomadura keratinilytica $\mathrm{WCC}-2265^{\mathrm{T}}$ with $100 \%$ bootstrap value. The tree also showed that cellulase producers and non-cellulase producers in Thermomonosporaceae are grouped into different clades.
\end{abstract}

Keywords: Cellulase, Cisolok geothermal area, thermophilic Actinobacteria, soil

\section{INTRODUCTION}

Actinobacteria is one of the largest phyla within the domain Bacteria which comprises Gram-positive bacteria with high $\mathrm{G}+\mathrm{C}$ content in their DNA. They are frequently found in soil due to their abilities in carbon cycling (Edwards 1993), and are mostly mesophilic (Satyanarayana et al. 2013). Actinobacteria can also be found in hightemperature habitats such as geothermal areas, deserts, and deep-sea hydrothermal vents (Satyanarayana et al. 2013), with growth temperatures, range from 40 to $80^{\circ} \mathrm{C}$ (Shivlata and Satyanarayana 2015). These thermophilic Actinobacteria has gained interest and are largely studied for their metabolites production, such as various antibiotics and industrial important thermostable enzyme (Hamedi and Wink 2017; Lewin et al. 2017).

Thermophilic Actinobacteria were reported to produced many important enzymes, such as amylases, cellulases, lipases, proteases, and xylanases. Studies on extracellular enzymes produced by thermophilic Actinobacteria have garnered interest for application in various industries due to their thermostability (Satyanarayana et al. 2013). The advantages of thermostable enzymes from thermophiles include great stability, and enhanced activity in the presence of common protein denaturants (Matsui et al. 2000). They also reduce the risk of contamination (Haki and Rakshit 2003). Cellulases, as one of important enzymes, are widely used in several industries, such as textiles, pulps, and biofuels (Satyanarayana et al. 2013). Cellulases act upon cellulose by breaking the polysaccharide down into oligosaccharide and glucose (Rani et al. 2016).

Cellulose is one of the most abundant polysaccharides and is a major component of plants, composed of glucose units linked by $\beta$-1,4-glycosidic bonds (Sharma and Yazdani 2016). Thermostable cellulases are required to break the crystalline celluloses, such as biopolishing of cotton fabric in the textile industry because it is a more efficient process at high temperature (Ando et al. 2002). Cellulase-producing bacteria have more advantages than fungi e.g. better stability, shorter generation time, easy to cultivate using inexpensive carbon and nitrogen sources, and larger amount of enzymes secreted ( $\mathrm{Li}$ et al. 2008). Additionally, several thermophilic Actinobacteria have been reported as cellulase producers, for example, 
Thermomonospora cellulolytica YIM $77510^{\mathrm{T}}$ and $T$. amylolytica YIM $77502^{\mathrm{T}}$ (Jiao et al. 2015), Actinomadura keratinilytica T16-1 (Sukkhum et al. 2011), and $A$. miaoliensis TF1 (Sriyapai et al. 2018).

The studies on thermophilic Actinobacteria from extreme environments e.g. volcanic areas, hydrothermal areas, and geysers, are still either unexplored or less-explored which showed promising researches for exploring their potential as thermostable enzyme producers (Mehta and Satyanarayana 2013). The Cisolok geothermal area, as one of less-explored extreme environments in West Java, is one of the potential habitats which has high microbial diversity with Proteobacteria and Cyanobacteria as major abundant phyla (Seo et al. 2012). Previous studies by Yokota et al. (2016) and Mawarid et al. (2016) reported that thermophilic bacteria identified as Paenibacillus cisolokensis and Brevibacillus sp., respectively, isolated from the litter of Cisolok geothermal area, which showed positive results for cellulase enzyme activity at temperature of $50^{\circ} \mathrm{C}$.

Previous study by Sjamsuridzal et al. (unpublished data), successfully obtained 17 thermophilic Actinobacteria isolates from soil in Cisolok geothermal area. Syafitri et al. (2019) reported that all of these Actinobacteria isolates could grow at $45^{\circ} \mathrm{C}$, and 15 of the 17 isolates showed amylolytic activity at $45^{\circ} \mathrm{C}$. According to Shivlata and Satyanarayana (2015), thermophilic Actinobacteria are able to grow in temperatures ranging from 40 to $80^{\circ} \mathrm{C}$. A similar observation was reported by Kumar et al. (2014), where thermophilic bacteria isolated from the Manikaran hot springs in India had growth in a temperature range of 45 to $70^{\circ} \mathrm{C}$. However, until recently, the reports regarding cellulose-degrading thermophilic Actinobacteria from soil in Cisolok geothermal area, has not been described yet. The aims of this study were to investigate the cellulolytic activity of thermophilic Actinobacteria isolated from soil in the Cisolok geothermal area and to identify potential thermophilic Actinobacteria that show cellulolytic activity at high temperatures.

\section{MATERIALS AND METHODS}

\section{Source of isolates}

The 17 isolates used in this study were obtained from five soil samples taken from the Cisolok geysers at three sampling locations. Seven isolates (SL1-1-R-2, SL1-1-R-4, SL1-1-R-7, SL1-1-R-8, SL1-2-R-2, SL1-2-R-3, and SL1-2R-4) were obtained from soil around a big geyser (6 57'221'S, 106 27'507'E), three isolates (SL2-2-R-1, SL2-2-R-12, and SL2-2-R-15) were obtained from soil around a small geyser (6 $\left.6^{\circ} 7^{\prime} 189^{\prime \prime} S, 106^{\circ} 27^{\prime} 365^{\prime \prime} \mathrm{E}\right)$, and seven isolates (SL3-1-R-14, SL3-1-R-16, SL3-2-R-5, SL32-R-17, SL3-2-R-18, SL3-2-R-33, and SL3-2-R-37) were obtained from forest soil near a geyser (6 $657^{\circ} 482^{\prime \prime} \mathrm{S}$, $\left.106^{\circ} 28^{\prime} 655^{\prime \prime} \mathrm{)}\right)$. Thermophilic Actinobacteria were isolated according to Yabe et al. (2017) and Ningsih et al. (2019) with some modifications. The isolation was performed using 1\% International Streptomyces Project (ISP) 1 agar medium incubated at $45^{\circ} \mathrm{C}$ for 3 to 4 weeks.

Pure isolates were grown on ISP 1 agar medium at $45^{\circ} \mathrm{C}$ for 7 days. All of the isolates were preserved as agar block in $20 \%(\mathrm{v} / \mathrm{v})$ glycerol solution at $-80^{\circ} \mathrm{C}$ and as lyophilized cells using the L-drying method for long-term preservation (Ningsih et al. 2019). All isolates are deposited in the Universitas Indonesia Culture Collection (UICC), Department of Biology, Faculty of Mathematics and Natural Sciences, Universitas Indonesia, in Depok, Indonesia.

\section{Cellulolytic activity assay}

Screening of cellulolytic activity of 17 thermophilic Actinobacteria isolates was performed on minimal (Mm) agar with the addition of $1 \%(\mathrm{w} / \mathrm{v})$ carboxymethyl cellulose (CMC) as a substrate and incubated at $45,50,55$, and $60^{\circ} \mathrm{C}$ for up to 7 days. The cellulolytic activity was observed after 3 and 7 days of incubation by staining the plates with $0.2 \%(\mathrm{w} / \mathrm{v})$ Congo red and then rinsing twice with $1 \mathrm{M}$ $\mathrm{NaCl}$ solution. The formation of a clear zone around a bacterial colony indicated the hydrolysis of cellulose (Meddeb-Mouelhi et al. 2014). The experiment was carried out in triplicate. The potential isolates with positive cellulolytic activity up to $60^{\circ} \mathrm{C}$ were subjected to cellulolytic activity assay on $\mathrm{Mm}$ agar with the addition of $1 \%(\mathrm{w} / \mathrm{v})$ microcrystalline cellulose (MCC) as a substrate and incubated at $45^{\circ} \mathrm{C}$ for 7 days. The enzyme activity was observed by staining the plates with $0.2 \%$ (w/v) Congo red and washing twice with $1 \mathrm{M} \mathrm{NaCl}$ solution. A clear zone formation around the bacterial colony would indicate the enzyme activity.

\section{Molecular identification based on 16S rRNA gene sequence}

The isolates were grown in ISP 1 broth medium for 7 days at $45^{\circ} \mathrm{C}$ and mycelium was harvested by centrifugation. Genomic DNA was extracted using a Genomic DNA Mini Kit (Blood/Cultured Cell) (Geneaid, New Taipei City, Taipei) according to the manufacturer's protocol. The 16S rRNA gene was amplified using MyTaq Red Mix (Bioline, London) with two universal primers: 9F (5'-GAGTTTGATCCTGGCTCAG-3') and 1510R (5'GGCTACCTTGTTACGA-3') (Weisburg et al. 1991). The PCR reactions were carried out as follows: initial denaturation at $95^{\circ} \mathrm{C}$ for $3 \mathrm{~min}$ followed by 35 cycles of denaturation at $95^{\circ} \mathrm{C}$ for $15 \mathrm{sec}$, annealing at $56^{\circ} \mathrm{C}$ for 15 sec and extension at $72^{\circ} \mathrm{C}$ for $10 \mathrm{sec}$. The PCR products were sequenced using four universal eubacterial primers 27F (5'-AGAGTTTGATCMTGGCTCAG-3'; Escherichia coli positions 8-27), 785F (5'-GGATTAGATACCCTGGTA-3'), 800R (5'-TACCAGGGTATCTAATCC-3'), and 1492R (5'-TACGGYTACCTTGTTACGACTT-3'; E. coli positions 1492-1510) (Weisburg et al. 1991; Jin et al. 2015) by $1 \mathrm{st}$ BASE Sequencing Service, Malaysia (https://baseasia.com/dna-sequencing-services.com). Sequences obtained in this study were analyzed using the software program ChromasPro V.2.1.8. (Technelysium, Tewantin, Australia) and then compared with sequence on the EzBioCloud Database (https://www.ezbiocloud.net/) (Yoon et al. 2017). A phylogenetic tree was constructed according to the neighbor-joining method used by Saitou and Nei (1987) with the MEGA 7.0 program (Kumar et al. 2016). 
Distance matrices for the aligned sequences were calculated by the two-parameter method used by Kimura (1980). The robustness of individual branches was estimated by the bootstrapping of 1,000 replications (Felsenstein 1985).

\section{RESULTS AND DISCUSSION}

\section{Cellulolytic activity assay}

Screening for cellulolytic activity was performed by incubating the isolates at $45,50,55$, and $60^{\circ} \mathrm{C}$ on $\mathrm{Mm}$ agar medium with $\mathrm{CMC}$ as substrate. The results of the enzyme screening are shown in Table 1. In total, 15 isolates were able to hydrolyze CMC after being incubated for 3 days at $45^{\circ} \mathrm{C}$. Fourteen out of 17 isolates showed cellulolytic activity on a CMC agar medium after being incubated for 3 to 7 days at $50^{\circ} \mathrm{C}$. Only four isolates showed $\mathrm{CMC}$ hydrolysis after being incubated for 3 to 7 days at $55^{\circ} \mathrm{C}$. A cellulase assay was conducted for four isolates with positive cellulolytic activity at $55^{\circ} \mathrm{C}$ and then at $60^{\circ} \mathrm{C}$. After being incubated for up to 7 days, only three isolates (SL1-2-R-2, SL1-2-R-3, and SL1-2-R-4) showed cellulolytic activity on CMC agar medium at $60^{\circ} \mathrm{C}$. Cellulolytic activity on the CMC agar medium was detected by the formation of a clear zone on the plates, as seen in Figure 1.

Isolates that showed cellulolytic activity on the CMC agar medium were able to hydrolyze $\beta$-1,4-glycosidic linkage in cellulose to a monomeric unit of glucose. Cellulase belongs to the glycoside hydrolases that are able to hydrolyze glycoside bonds (Satyanarayana et al. 2013). The cellulase system has three major groups based on their catalytic action: endoglucanase, exoglucanase, and $\beta$ glucosidase. Therefore, using a different substrate might give different cellulolytic activity results (Lynd et al. 2002). Endoglucanase cleaves at random internal amorphous regions of the cellulose polysaccharide chain and releases oligosaccharides and new chain ends (Lynd et al. 2002). Carboxymethyl cellulose (CMC) is soluble cellulose derivate that is used as a standard substrate for endoglucanase production because of its amorphous cellulose form (Tang et al. 2011). Amorphous noncrystalline regions are attacked in the initial stages of cellulose breakdown because of their accessibility, which makes them more easily hydrolyzed (Sharma and Yazdani 2016). The ability to hydrolyze CMC showed that the isolates were able to produce endoglucanase. Detection of endoglucanase activity was performed by staining on agar plate with dyes. Residual long chains of polysaccharide on an agar plate will adsorb the dyes, therefore, the part of the plate with hydrolyzed polysaccharides will show a clear zone as the activity of endoglucanase (Tang et al. 2011).

Bacterial isolate SL2-2-R-15 showed growth on the $\mathrm{CMC}$ agar medium at 45 to $55^{\circ} \mathrm{C}$ while SL3-1-R-16 showed growth at 45 to $50^{\circ} \mathrm{C}$. However, these isolates did not show cellulolytic activity after being incubated on the CMC agar medium for up to 7 days. The result showed that these two isolates (SL2-2-R-15 and SL3-1-R-16) were able to grow on the CMC agar medium but not able to hydrolyze CMC as a substrate. Carboxymethyl cellulose (CMC) is generally used for endoglucanase production, and some organisms cannot hydrolyze CMC (Lynd et al. 2002). Although the isolates were not able to use CMC as a substrate, they were still able to grow on CMC agar medium because the assay medium consisted of yeast extract and agar. Yeast extract contains amino acids, peptides, water-soluble vitamins, and carbohydrates that can be used as nutrient sources for microorganisms (Costa et al. 2002). Agar used as a bacteriological media consists of two polysaccharides, agarose, and agaropectin (Suzuki et al. 2003). Some microorganisms are able to hydrolyzed agar by producing agarase and metabolize it as carbon and energy source (Chi et al. 2012).

Table 1. Cellulolytic activity of 17 Actinobacteria isolates after 3 and 7 days of incubation at $45,50,55$, and $60^{\circ} \mathrm{C}$

\begin{tabular}{|c|c|c|c|c|c|c|c|c|c|}
\hline \multirow{3}{*}{ Isolate code } & \multicolumn{8}{|c|}{ CMC } & \multirow{3}{*}{$\begin{array}{c}\mathrm{MCC} \\
45^{\circ} \mathrm{C} \\
7 d\end{array}$} \\
\hline & \multicolumn{2}{|c|}{$45^{\circ} \mathrm{C}$} & \multicolumn{2}{|c|}{$50^{\circ} \mathrm{C}$} & \multicolumn{2}{|c|}{$55^{\circ} \mathrm{C}$} & \multicolumn{2}{|c|}{$60^{\circ} \mathrm{C}$} & \\
\hline & 3d & $7 d$ & 3d & $7 d$ & 3d & $7 d$ & 3d & 7d & \\
\hline SL1-1-R-2 & + & + & + & + & $*$ & $*$ & $\mathrm{n} / \mathrm{a}$ & $\mathrm{n} / \mathrm{a}$ & $\mathrm{n} / \mathrm{a}$ \\
\hline SL1-1-R-4 & + & + & + & + & $*$ & $*$ & $\mathrm{n} / \mathrm{a}$ & $\mathrm{n} / \mathrm{a}$ & $\mathrm{n} / \mathrm{a}$ \\
\hline SL1-1-R-7 & + & + & + & + & $*$ & $*$ & $\mathrm{n} / \mathrm{a}$ & $\mathrm{n} / \mathrm{a}$ & $\mathrm{n} / \mathrm{a}$ \\
\hline SL1-1-R-8 & + & + & + & + & $*$ & $*$ & $\mathrm{n} / \mathrm{a}$ & $\mathrm{n} / \mathrm{a}$ & $\mathrm{n} / \mathrm{a}$ \\
\hline SL1-2-R-2 & + & + & + & + & + & + & $\mathrm{n} / \mathrm{a}$ & + & + \\
\hline SL1-2-R-3 & + & + & + & + & + & + & $\mathrm{n} / \mathrm{a}$ & + & + \\
\hline SL1-2-R-4 & + & + & + & + & + & + & $\mathrm{n} / \mathrm{a}$ & + & + \\
\hline SL2-2-R-1 & + & + & + & + & + & + & $*$ & $*$ & $\mathrm{n} / \mathrm{a}$ \\
\hline SL2-2-R-12 & + & + & + & + & $*$ & $*$ & $\mathrm{n} / \mathrm{a}$ & $\mathrm{n} / \mathrm{a}$ & $\mathrm{n} / \mathrm{a}$ \\
\hline SL2-2-R-15 & - & - & - & - & - & - & $\mathrm{n} / \mathrm{a}$ & $\mathrm{n} / \mathrm{a}$ & $\mathrm{n} / \mathrm{a}$ \\
\hline SL3-1-R-14 & + & + & $*$ & + & $*$ & $*$ & $\mathrm{n} / \mathrm{a}$ & $\mathrm{n} / \mathrm{a}$ & $\mathrm{n} / \mathrm{a}$ \\
\hline SL3-1-R-16 & - & - & - & - & $*$ & $*$ & $\mathrm{n} / \mathrm{a}$ & $\mathrm{n} / \mathrm{a}$ & $\mathrm{n} / \mathrm{a}$ \\
\hline SL3-2-R-5 & + & + & + & + & $*$ & $*$ & $\mathrm{n} / \mathrm{a}$ & $\mathrm{n} / \mathrm{a}$ & $\mathrm{n} / \mathrm{a}$ \\
\hline SL3-2-R-17 & + & + & + & + & $*$ & $*$ & $\mathrm{n} / \mathrm{a}$ & $\mathrm{n} / \mathrm{a}$ & $\mathrm{n} / \mathrm{a}$ \\
\hline SL3-2-R-18 & + & + & $*$ & $*$ & $*$ & $*$ & $\mathrm{n} / \mathrm{a}$ & $\mathrm{n} / \mathrm{a}$ & $\mathrm{n} / \mathrm{a}$ \\
\hline SL3-2-R-33 & + & + & + & + & $*$ & $*$ & $\mathrm{n} / \mathrm{a}$ & $\mathrm{n} / \mathrm{a}$ & $\mathrm{n} / \mathrm{a}$ \\
\hline SL3-2-R-37 & + & + & + & + & $*$ & $*$ & $\mathrm{n} / \mathrm{a}$ & $\mathrm{n} / \mathrm{a}$ & $\mathrm{n} / \mathrm{a}$ \\
\hline Total positive cellulolytic activity & 15 & 15 & 13 & 14 & 4 & 4 & $\mathrm{n} / \mathrm{a}$ & 3 & 3 \\
\hline
\end{tabular}

Note: (+): positive cellulolytic activity; (-): negative cellulolytic activity; (*): no growth; (n/a): data not available 


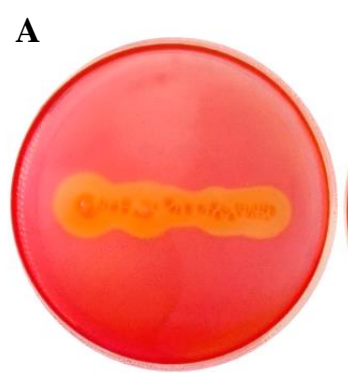

SL1-2-R-2

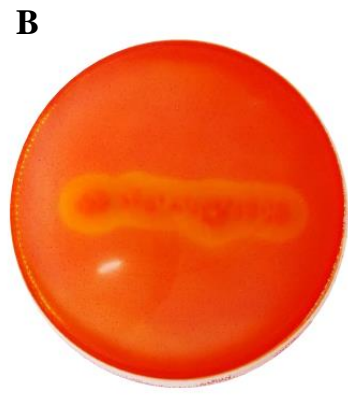

SL1-2-R-2

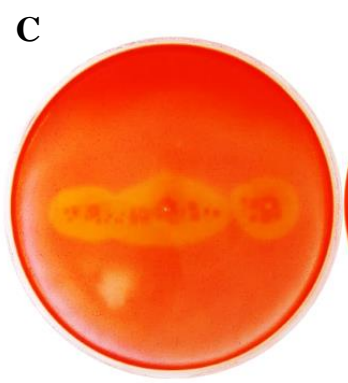

SL1-2-R-2

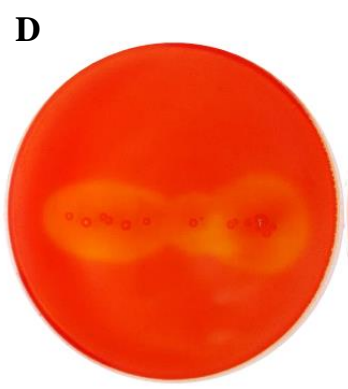

SL1-2-R-2

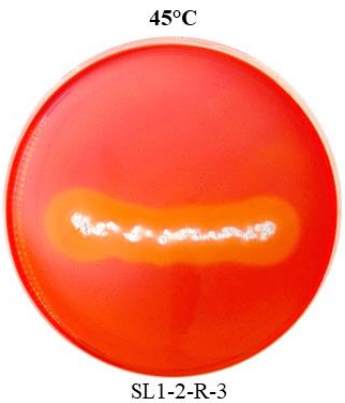

SL1-2-R-3

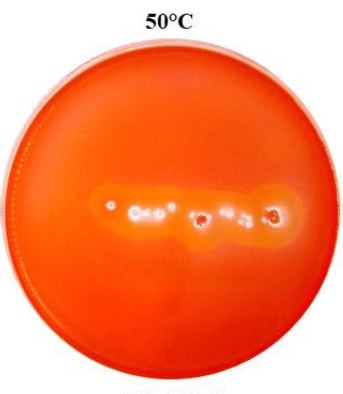

SL1-2-R-3

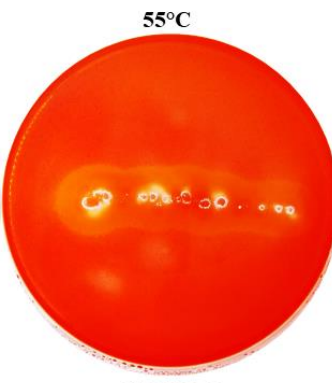

SL1-2-R-3

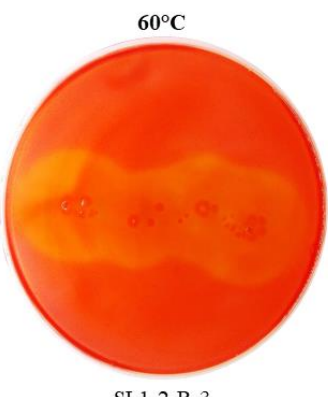

SL1-2-R-3

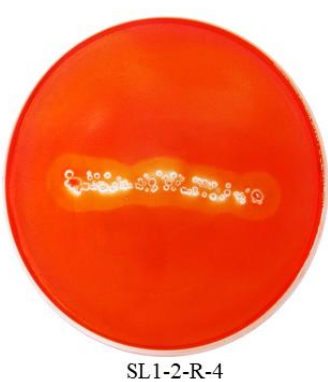

SL1-2-R-4

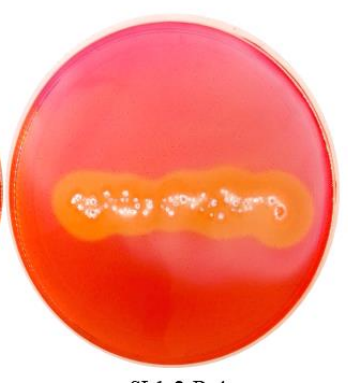

SL1-2-R-4

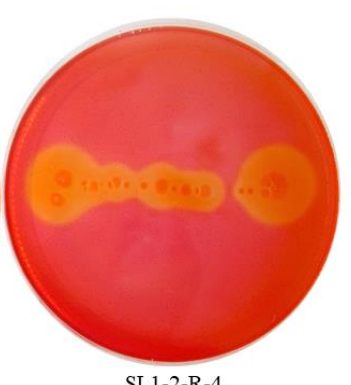

SL1-2-R-4

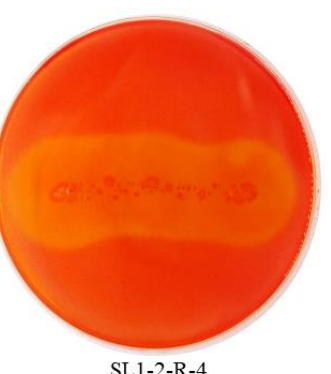

$1 \mathrm{~cm}$

Figure 1. Isolates with positive cellulolytic activity on $\mathrm{CMC}$ agar medium after 3 days of incubation at: A. $45^{\circ} \mathrm{C}, \mathrm{B} .50^{\circ} \mathrm{C}, \mathrm{C} .55^{\circ} \mathrm{C}, \mathrm{D}$. After 7 days of incubation at $60^{\circ} \mathrm{C}$

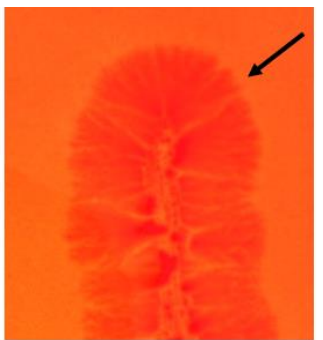

SL1-2-R-2

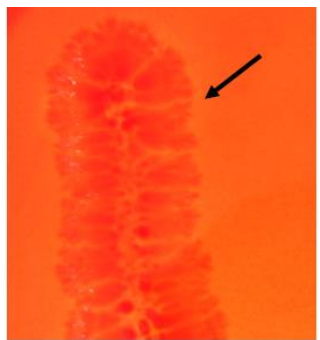

SL1-2-R-3

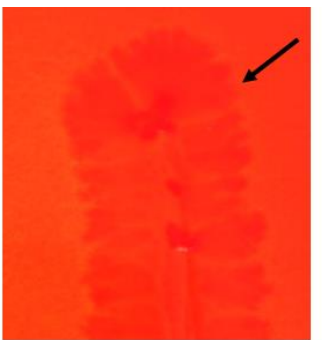

SL1-2-R-4

Figure 2. Positive result of cellulolytic activity on MCC medium after 7 days of incubation at $45^{\circ} \mathrm{C}$ 
Screening for cellulolytic activity on MCC agar medium was performed for the three potential isolates (SL1-2-R-2, SL1-2-R-3, and SL1-2-R-4) with positive cellulolytic activity on $\mathrm{CMC}$ agar medium at $60^{\circ} \mathrm{C}$. The results showed that the three isolates were able to grow and show cellulolytic activity on MCC agar medium at a temperature of $45^{\circ} \mathrm{C}$ after being incubated for 7 days. Clear zones were weakly detected on MCC agar medium as seen in Figure 2. The result of this study showed that three isolates were also able to produce exoglucanase. Microcrystalline cellulose (MCC) was used to detect the ability of isolates to produce exoglucanase (Lynd et al. 2002). Exoglucanase acts on the reducing or nonreducing ends of the cellulose polysaccharide chain and releases cellobiose as a product. Exoglucanase presumably acts by peeling cellulose chain from the microcrystalline structure. Cellulose has two regions, amorphous and crystalline, where amorphous regions are more accessible to enzyme degradation, while crystalline cellulose molecules have constituent molecules of individual microfibrils that are packed tightly. Thus, they are recalcitrant to be hydrolyzed by enzymes (Sharma and Yazdani 2016). The hydrolysis of MCC needs the synergism of endoglucanase and exoglucanase, which is called exo-endo synergy. Exo-endo synergy leads endoglucanase to release cellulose chains with new ends and thus becomes available to be attacked by exoglucanase (Bettache et al. 2018).

This study showed that three thermophilic Actinobacteria isolates (SL1-2-R-2, SL1-2-R-3, and SL12-R-4) were able to show cellulolytic activity on CMC and MCC agar media which means these isolates have the ability to produce endoglucanase and exoglucanase (Tang et al. 2011). Previous study reported that two Streptomyces strains, M7a and M23, isolated from forest soil were able to produce complete cellulase systems, including endoglucanases, exoglucanases, and $\beta$-glucosidases, to degrade cellulose to monomer glucose (Semêdo et al. 2000). Several factors that affect the growth and enzyme production of thermophilic Actinobacteria are temperature, $\mathrm{pH}$, and nutrients. According to Al-Tai et al. (1989) and Manivasagan et al. (2010), Actinobacteria have the ability to show cellulolytic activity in a $\mathrm{pH}$ range from 4 to 9 . In another study, Jiao et al. (2015) isolated and identified Thermomonospora cellulosilytica YIM $77510^{\mathrm{T}}$ and $T$. amylolytica YIM $77502^{\mathrm{T}}$ from geothermally heated soil in Tengchong county, China, that were able to produce cellulase and grow at 25 to $55^{\circ} \mathrm{C}$ with the optimum growth temperature at $45^{\circ} \mathrm{C}$. Several studies reported that growth and cellulases production of Actinobacteria such as Thermomonospora curvata are promoted by the addition of yeast extract in the medium as a nitrogen source (Semêdo et al. 2000).

\section{Molecular identification based on 16S rRNA gene sequences}

Molecular identification based on 16S rRNA gene sequences was performed for three isolates with cellulolytic activity at $60^{\circ} \mathrm{C}$. All three isolates (SL1-2-R-2, SL1-2-R-3, and SL1-2-R-4) are closely related to Actinomadura keratinilytica $\mathrm{WCC}-2665^{\mathrm{T}}$, with $100 \%$ (SL1-2-R-2 and SL1-2-R-4) and 99.93\% (SL1-2-R-3) similarities. Actinomadura keratinilytica $\mathrm{WCC}-2665^{\mathrm{T}}$ is a thermophilic Actinobacteria in the family Thermomonosporaceae with growth temperature ranges from 30 to $55^{\circ} \mathrm{C}$; however, there is still no information about the cellulolytic activity of $A$. keratinilytica from type strain WCC-2665 ${ }^{\mathrm{T}}$ (Puhl et al. 2009). Sukkhum et al. (2011) identified A. keratinilytica strain T16-1 isolated from soil in Huai Kha Khaeng Wildlife Sanctuary, Uthaithani province, Thailand which was able to degrade cellulose and grow at temperatures of 30 to $60^{\circ} \mathrm{C}$.

A phylogenetic tree analysis of the three isolates along with other species from the genus Actinomadura and other genera in the family Thermomonosporaceae, showed that most of the species are thermophilic Actinobacteria (see Table 2). The members of the family Thermomonosporaceae are mainly found in soil, and some of them have been isolated from compost. Some genera of Thermomonosporaceae are also known as enzyme producers such as Actinomadura gamaensis NEAU-Gz5 ${ }^{\mathrm{T}}$ (cellulase; Abagana et al. 2016), Actinomadura kijaniata NBRC $14229^{\mathrm{T}}$ (amylase, xylanase, urease; Horan and Brodsky 1982), Thermomonospora curvata DSM $43183^{\mathrm{T}}$ (CMCase, xylanase; Goodfellow and Trujillo 2012), and Actinocorallia herbida ATCC $51528^{\mathrm{T}}$ (amylase; Iinuma et al. 1994). The phylogenetic tree showed that the genera Actinomadura are paraphyletic in the family Thermomonosporaceae. Actinomadura appears in the same clade as the genera Spirillospora and Actinocorallia (Figure 3). This finding is similar to a previous report of Nouioui et al. (2018), showing that the type genus of Thermomonosporaceae appears to be paraphyletic and that some Actinomadura species showed an uncertain position within Thermomonosporaceae. The phylogenetic tree also showed that cellulase producers and non-cellulase producers in Thermomonosporaceae are grouped into different clades. Based on an alignment comparison of sequence position in the 16S rRNA gene, there are two sites that appear to determine the difference between the cellulase and non-cellulase producers. The differences were located in A. keratinilytica $\mathrm{WCC}-2265^{\mathrm{T}}$ at positions 976 and 1011, which were determined to be cytosine and guanine, respectively, in the $16 \mathrm{~S}$ rRNA gene analysis of the cellulase producers clade. In the $16 \mathrm{~S}$ rRNA gene of the non-cellulase producer's clade, sites 976 and 1011 were determined to be guanine and cytosine, respectively. 


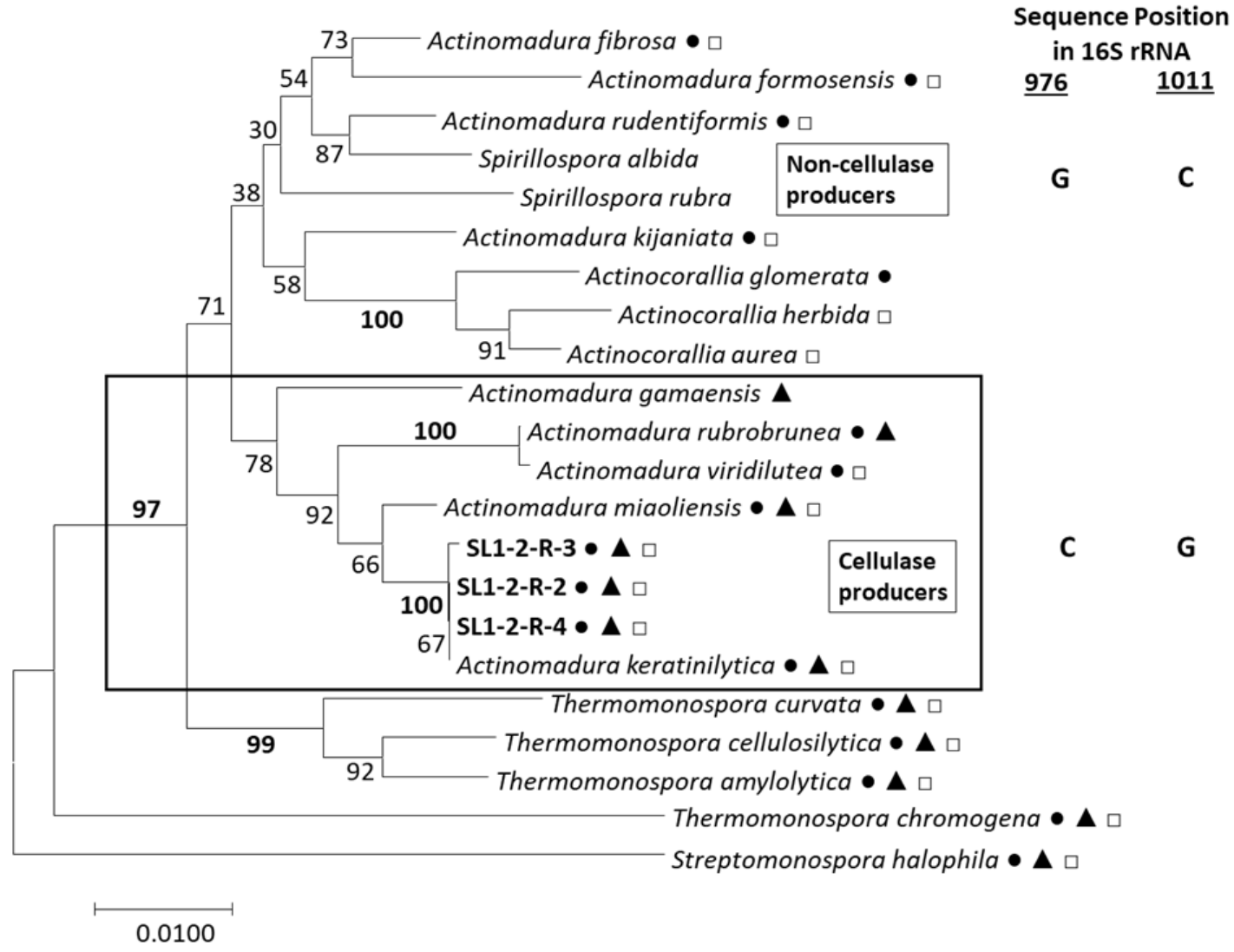

Figure 3. Bootstrapped neighbor-joining tree, inferred from 1272 aligned sites of 16S rRNA gene sequence, showing phylogenetic relationships among three isolates used in this study and closely-related taxa in the family Thermomonosporaceae. Streptomonospora halophila YIM $9155^{\mathrm{T}}$ was used as an outgroup. Bootstrap values at branching points are expressed as percentages from 1000 replications. The scale bar indicates 1 base change per 100 nucleotide positions. Bracketed group assigned to the thermophilic cellulase producers lineage. Note: $(\bullet)$ : thermophilic; $(\boldsymbol{\Lambda})$ : cellulase producer; $(\square)$ : other enzymes producer

Table 2. List of Operational Taxonomic Units (OTUs) used in the phylogenetic analysis

\begin{tabular}{|c|c|c|c|c|c|}
\hline Species & Strain & $\begin{array}{c}\text { DNA database } \\
\text { accession no. }\end{array}$ & $\begin{array}{l}\text { Growth range } \\
\text { temperature }\end{array}$ & Source & Reference \\
\hline Actinomadura keratinilytica & SL1-2-R-2 & LC484202 & $25-60^{\circ} \mathrm{C}$ & Soil & This study \\
\hline Actinomadura keratinilytica & SL1-2-R-3 & LC484203 & $25-60^{\circ} \mathrm{C}$ & Soil & This study \\
\hline Actinomadura keratinilytica & SL1-2-R-4 & LC484204 & $25-60^{\circ} \mathrm{C}$ & Soil & This study \\
\hline \multirow[t]{2}{*}{ Actinomadura keratinilytica } & WCC-2265 & EU637009 & $30-55^{\circ} \mathrm{C}$ & Compost & Puhl et al. (2009) \\
\hline & $\mathrm{T} 16-1$ & - & $30-60^{\circ} \mathrm{C}$ & Soil & Sukkhum et al. (2011) \\
\hline \multirow[t]{2}{*}{ Actinomadura miaoliensis } & $\mathrm{BC} 44 \mathrm{~T}-5^{\mathrm{T}}$ & EF116925 & $25-55^{\circ} \mathrm{C}$ & Compost & Tseng et al. (2009) \\
\hline & TF1 & - & $40-60^{\circ} \mathrm{C}$ & soil & Sriyapai et al. (2018) \\
\hline Actinomadura rubrobrunea & NBRC $15275^{\mathrm{T}}$ & BCQU01 000204 & $37-65^{\circ} \mathrm{C}$ & Soil & Goodfellow and Trujillo (2012) \\
\hline Actinomadura viridilutea & IFO14480 & D86943 & $37-65^{\circ} \mathrm{C}$ & Desert soil & Goodfellow and Trujillo (2012) \\
\hline Actinomadura gamaensis & NEAU-Gz5 ${ }^{\mathrm{T}}$ & КT989505 & $15-40^{\circ} \mathrm{C}$ & Soil & Abagana et al. (2016) \\
\hline Actinomadura formosensis & NBRC $14204^{\mathrm{T}}$ & AJ293703 & $23-41^{\circ} \mathrm{C}$ & Soil & Goodfellow and Trujillo (2012) \\
\hline Actinomadura kijaniata & NBRC $14229^{\mathrm{T}}$ & BCQR01 000335 & $28-50^{\circ} \mathrm{C}$ & Soil & Horan and Brodsky (1982) \\
\hline Actinomadura fibrosa & ATCC $49459^{\mathrm{T}}$ & AF163114 & $20-45^{\circ} \mathrm{C}$ & Soil & Goodfellow and Trujillo (2012) \\
\hline Actinomadura rudentiformis & $\mathrm{HMC} 1^{\mathrm{T}}$ & DQ285420 & $30-45^{\circ} \mathrm{C}$ & Soil & Goodfellow and Trujillo (2012) \\
\hline Thermomonospora cellulosilytica & YIM $77510^{\mathrm{T}}$ & AB859254 & $25-55^{\circ} \mathrm{C}$ & Soil & Jiao et al. (2015) \\
\hline Thermomonospora amylolytica & YIM $77502^{\mathrm{T}}$ & AB859253 & $25-55^{\circ} \mathrm{C}$ & Soil & Jiao et al. (2015) \\
\hline Thermomonospora curvata & DSM $43183^{\mathrm{T}}$ & AF002262 & $30-53^{\circ} \mathrm{C}$ & Compost & Goodfellow and Trujillo (2012) \\
\hline Thermomonospora chromogena & ATCC $43196^{\mathrm{T}}$ & AF116558 & $40-53^{\circ} \mathrm{C}$ & Compost & Goodfellow and Trujillo (2012) \\
\hline Actinocorallia herbida & ATCC $51528^{\mathrm{T}}$ & D85473 & $12-38^{\circ} \mathrm{C}$ & Soil & Iinuma et al. (1994) \\
\hline Actinocorallia aurea & DSM $44434^{\mathrm{T}}$ & $\mathrm{AB} 006177$ & $20-30 ; 37^{\circ} \mathrm{C}$ & Soil & Tamura et al. (2007) \\
\hline Actinocorallia glomerata & NBRC $15960^{\mathrm{T}}$ & AJ293704 & $7-41^{\circ} \mathrm{C}$ & Compost & Goodfellow and Trujillo (2012) \\
\hline Spirillospora albida & ATCC $15331^{\mathrm{T}}$ & D85498 & $18-35^{\circ} \mathrm{C}$ & Soil & Goodfellow and Trujillo (2012) \\
\hline Spirillospora rubra & JCM $6875^{\mathrm{T}}$ & AF163123 & $20-37^{\circ} \mathrm{C}$ & Soil & Goodfellow and Trujillo (2012) \\
\hline
\end{tabular}


In conclusion, Actinobacteria isolated from soils in the Cisolok geothermal areas are thermophiles. All of the isolates were able to grow at temperatures ranging from 45 to $60^{\circ} \mathrm{C}$. The thermophilic Actinobacteria isolates are also potential producers of the cellulase enzyme as demonstrated by $\mathrm{CMC}$ hydrolysis at temperatures of $45^{\circ} \mathrm{C}$ by 15 isolates, $50^{\circ} \mathrm{C}$ by 14 isolates, $55^{\circ} \mathrm{C}$ by four isolates, and $60^{\circ} \mathrm{C}$ by three isolates, and $\mathrm{MCC}$ hydrolysis at temperature of $45^{\circ} \mathrm{C}$ by three isolates. The three isolates (SL1-2-R-2, SL1-2-R-3, and SL1-2-R-4) that showed positive cellulolytic activity were able to hydrolyze both CMC and MCC as substrates. This result indicates that isolates from soil of geothermal area could produce cellulase at high temperatures. The molecular identification based on $16 \mathrm{~S}$ rRNA gene sequences showed that three isolates with positive cellulolytic activity at $60^{\circ} \mathrm{C}$ are closely related to Actinomadura keratinilytica from family Thermomonosporaceae that is known as thermophiles and enzymes producer. Further studies are needed, especially for confirmation of thermostable cellulase production from these isolates.

\section{ACKNOWLEDGEMENTS}

This research was fully funded by Hibah Publikasi Internasional Terindeks untuk Tugas Akhir Mahasiswa (PITTA) UI 2018 no. 2331/UN2.R3.1/HKP.05.00/2018 to W.S. and supported by S.Y from Department of Microbial Resources, Graduate School of Agricultural Sciences, Tohoku University, Japan.

\section{REFERENCES}

Abagana AY, Sun P, Liu C, Cao T, Zheng W, Zhao S, Xiang W, Wang X. 2016. Actinomadura gamaensis sp. nov., a novel actinomycete isolated from soil in Gama, Chad. Antonie Leeuwenhoek 109 (6): 833-839.

Al-Tai AM, Abdul-Razzak S, Al-Attiyah SS, Abdul-Nour BA. 1989 Cellulase production from Actinomycetes isolated from Iraqi soils: II. Cell growth and cellulase activity of Streptomyces sp. strain AT7 different temperatures. J Islamic Acad Sci 2 (3): 185-188.

Ando S, Ishida H, Kosugi Y, Ishikawa K. 2002. Hyperthermostable endoglucanase from Pyrococcus horikoshii. Appl Environ Microbiol 68 (1): 430433.

Bettache A, Azzouz Z, Boucherba N, Bouiche C, Hamma S. 2018. Lignocellulosic biomass and cellulolytic enzymes of Actinobacteria. SAJ Biotechnol 5: 1-9.

Chi WJ, Chang YK, Hong SK. 2012. Agar degradation by microorganisms and agar-degrading enzymes. Appl Microbiol Biotechnol 94 (4): 917-930.

Costa E, Teixidó N, Usall J, Atarés E, Viñas I. 2002. The effect of nitrogen and carbon sources on growth of the biocontrol agent Pantoea agglomerans strain CPA-2. Lett Appl Microbiol 35 (2): 117 120.

Edwards C. 1993. Isolation properties and potential applications of thermophilic actinomycetes. Appl Biochem Biotechnol 42: 161-179.

Felsenstein J. 1985. Confidence limits on phylogenies: an approach using the bootstrap. Evolution 39 (4): 783-791.

Goodfellow M, Trujillo ME. 2012. Family III. Thermomonosporaceae Rainey, Ward-Rainey and Stackebrandt 1997, 486 emend. Zhang, Wang and Ruan 2001, 381 emend. Zhi, Li and Stackebrandt 2009 , 600. In: Goodfellow M, Kämpfer P, Busse H-J, Trujillo ME, Suzuki K, Ludwig W, Whitman WB. (eds) Bergey's Manual of Systematic Bacteriology, 2nd Edition. Springer, New York.
Haki, GD, Rakshit SK. 2003. Developments in industrially important thermostable enzymes: a review. Biores Technol 89: 17-34.

Hamedi J, Wink J. 2017. Introduction. In: Wink J, Mohammadipanah, Hamedi J (eds) Biology and Biotechnology of Actinobacteria. Springer, Gewerbestrase.

Horan AC, Brodsky BC. 1982. A novel antibiotic-producing Actinomadura, Actinomadura kijaniata sp. nov. Intl J Syst Evol Microbiol 32 (2): 195-200.

Iinuma S, Yokota A, Hasegawa T, Kanamaru T. 1994. Actinocorallia gen. nov., a new genus of the order Actinomycetales. Intl J Syst Bacteriol 44 (2): 230-234

Jiao J-Y, Liu L, Zhou E-M, Wei D-Q, Ming H, Xian W-D, Yuan C-G, Zhong J-M, Li W-J. 2015. Actinomadura amylolytica sp. nov. and Actinomadura cellulosilytica sp. nov., isolated from geothermally heated soil. Antonie Leeuwenhoek 108: 75-83.

Jin L, Lee HG, Ko SR, Ahn CY, Oh HM. 2015. Jatrophihabitans fulvus sp. nov., an actinobacterium isolated from grass soil. Int J Syst Evol Microbiol 65 (10): 3476-3480.

Kimura M. 1980. A simple method for estimating evolutionary rates of base substitutions through comparative studies of nucleotide sequences. J Mol Evol 16 (2): 111-120.

Kumar M, Yadav AN, Tiwari R, Prasanna R, Saxena AK. 2014. Deciphering the diversity of culturable thermotolerant bacteria from Manikaran hot springs. Ann Microbiol 64: 741-751

Kumar S, Stecher G, Tamura T. 2016. MEGA7: Molecular Evolutionary Genetics Analysis version 7.0 for bigger datasets. Mol Biol Evol 33 (7): 1870-1874

Lewin GR, Carlos C, Chevrette MG, Horn HA, McDonald BR, Stankey RJ, Fox BG, Currie CR. 2017. Evolution and ecology of Actinobacteria and their bioenergy applications. Annu Rev Microbiol 70: 235-254.

Li W, Zhang WW, Yang MM, Chen YL. 2008. Cloning of the thermostable cellulase gene from newly isolated Bacillus subtilis and its expression in Escherichia coli. Mol Biotechnol 40: 195-201.

Lynd LR, Weimer PJ, van Zyl WH, Pretorius IS. 2002. Microbial cellulose utilization: fundamentals and biotechnology. Microbiol Mol Biol Rev 66 (3): 506-577.

Manivasagan P, Gnanam S, Sivakumar K, Thangaradjou T, Vijayalakshmi S, Balasubramanian T. 2010. Isolation, identification, and characterization of multiple enzyme-producing Actinobacteria from sediment samples in Kodiyakarai coast, the Bay of Bengal. Afr J Microbiol Res 4 (14): 1550-1559.

Matsui I, Sakai Y, Matsui E, Kikuchi H, Kawarabayasi Y, Honda K. 2000. Novel substrate specificity of a membrane-bound $\beta$-glycosidase from the hyperthermophilic archaeon Pyrococcus horikoshii. FEBS Lett 467: 195-200.

Mawarid AT, Sjamsuridzal W, Yabe S, Santoso I, Ningsih F, Nurlaili DG, Oetari A, Yokota A. 2016. Polyphasic identification of a thermophilic bacterium from geyser of Cisolok, Indonesia. AIP Conf Proc 1729: 020067. DOI: $10.1063 / 1.4946970$.

Meddeb-Mouelhi F, Moisan JK, Beauregard M. 2014. A comparison of plate assay methods for detecting extracellular cellulase and xylanase activity. Enzyme Microb Technol 66: 16-19.

Mehta D, Satyanarayana T. 2013. Diversity of hot environments and thermophilic microbes. In: Satyanarayana $\mathrm{T}$, Littlechild J, Kawarabayasi Y (eds.). Thermophilic Microbes in Environmental and Industrial Biotechnology. Springer, Berlin.

Ningsih F, Yokota A, Sakai Y, Nanatani K, Yabe S, Oetari A, Sjamsuridzal W. 2019. Gandjariella thermophila gen. nov., sp. nov., a new member of the family Pseudonocardiaceae, isolated from forest soil in a geothermal area. Intl J Syst Evol Microbiol. DOI 10.1099/ijsem.0.003594

Nouioui I, Carro L, García-López M, Meier-Kolthoff J, Woyke T, Kyrpides NC, Pukall R, Klenk H-P, Goodfellow M, Göker M. 2018. Genome-based taxonomic classification of the phylum Actinobacteria. Front Microbiol 9.

Puhl AA, Selinger LB, McAllister TA, Inglis GD. 2009. Actinomadura keratinilytica sp. nov., a keratin-degrading actinobacterium isolated from bovine manure compost. Intl J Syst Evol Microbiol 59 (4): 828834.

Rani ME, Kumar NV, Gunaseeli R, Kannan ND. 2016. Comparative biochemistry and kinetics of microbial cellulase. In: Gupta VK (ed.) New and Future Developments in Microbial Biotechnology and Bioengineering: Microbial Cellulase System Properties and Applications. Elsevier, Amsterdam. 
Saitou N, Nei M. 1987. The neighbor-joining method: a new method for reconstructing phylogenetic trees. Mol Biol Evol 4 (4): 406-425.

Satyanarayana T, Littlechild J, Kawarabayasi Y. 2013. Thermophilic Microbes in Environmental and Industrial Biotechnology: Biotechnology of Thermophiles, 2nd ed. Springer, New York.

Semêdo LTAS, Gomes RC, Bon EPS, Soares RMA, Linhares LF, Coelho RRR. 2000. Endocellulase and exocellulase activities of two Streptomyces strains isolated from a forest soil. Appl Biochem Biotechnol 84-86: 267-276.

Seo MJ, Kim JN, Pyun YR. 2012. 16S rRNA gene sequence-based microbial diversity analyses of the geothermal areas of Cisolok, Kamojang, and Likupang in Indonesia. Korean $J$ Microbiol Biotechnol 40: 268-273.

Sharma S, Yazdani SS. 2016. Diversity of microbial cellulase system. In Gupta VK (ed.) New and Future Developments in Microbial Biotechnology and Bioengineering: Microbial Cellulase System Properties and Applications. Elsevier, Amsterdam.

Shivlata L, Satyanarayana T. 2015. Thermophilic and alkaliphilic Actinobacteria: biology and potential applications. Front Microbiol 6: 1014.

Sriyapai P, Chansiri K, Sriyapai T. 2018. Isolation and characterization of polyester-based plastics-degrading bacteria from compost soils. Microbiology 87 (2): 290-300.

Sukkhum S, Tokuyama S, Kongsaeree, Tamura T, Ishida Y, Kitpreechavanich V. 2011. A novel poly (L-lactide) degrading thermophilic actinomycetes, Actinomadura keratinilytica strain T16-1 and pla sequencing. Afr J Microbiol Res 5 (18): 2575-2582.

Suzuki H, Sawai Y, Suzuki T, Kawai K. 2003. Purification and characterization of an extracellular $\beta$-agarase from Bacillus sp. MK03. J Biosci Bioeng 95 (4): 328-334.

Syafitri WA, Ningsih, F, Setyaningsih PP, Rachmania MK, Sari DCAF, Yabe S, Yokota A, Oetari A, Sjamsuridzal W. 2019. Screening for amylolytic activity and characterization of thermophilic Actinobacteria isolated from a geothermal area in West Java, Indonesia. Biodiversitas 20 (7): 1929-1938.

Tamura T, Hatano K, Suzuki K. 2007. Classification of 'Sarraceniospora aurea' Furihata et al. 1989 as Actinocorallia aurea sp. nov. Intl J Syst Evol Microbiol 57: 2052-2055.

Tang W, Chen X, Zhang H, Chen F, Li X. 2011. Limitation of the development on cellulose hydrolysis by cellulase assay and search for the true cellulase degrading crystalline cellulose. In: Golan AE (ed.). Cellulase: Types and Action, Mechanism, and Uses. Nova Science Publishers, Inc. New York.

Tseng M, Yang SF, Hoang KC, Liao HC, Yuan GF, Liao CC. 2009. Actinomadura miaoliensis sp. nov., a thermotolerant polyesterdegrading actinomycete. Intl J Syst Evol Microbiol 59 (3): 517-520.

Weisburg, WG, Barns SM, Pelletier DA, Lane DJ. 1991. 16S ribosomal DNA amplification for phylogenetic study. J Bacteriol 173 (2): 697 703.

Yabe S, Sakai Y, Abe K, Yokota A, Také A, Matsumoto A, Sugiharto A, Susilowati D, Hamada D, Nara K, Sudiana IM, Otsuka S. 2017. Dictyobacter aurantiacus gen. nov., sp. nov., a member of the family Ktedonobacteraceae, isolated from soil, and emended description of the genus Thermosporothrix. Intl J Syst Evol Microbiol 67: 26152621.

Yokota A, Ningsih F, Nurlaili DG, Sakai Y, Yabe S, Oetari A, Santoso I, Sjamsuridzal W. 2016. Paenibacillus cisolokensis sp. nov., isolated from litter of a geyser. Intl J Syst Evol Microbiol 66: 3088-3094.

Yoon, SH, Ha SM, Kwon S, Lim J, Kim Y, Seo H, Chun J. 2017. Introducing EzBioCloud: A taxonomically united database of $16 \mathrm{~S}$ rRNA and whole-genome assemblies. Intl J Syst Evol Microbiol 67: 1613-1617. 